\title{
INVESTIGATING OF ENVIRONMENTAL AND HUMANISTIC ELEMENTS OF SUSTAINABLE ECOTOURISM IN THE STAIR-SHAPED ARCHITECTURE OF MIDDLE ZAGROS (CASE STUDY: HAJIIJ VILLAGE)
}

\author{
Seied Sajad Rahmatabady \\ Young Researchers and Elite Club, Shoushtar Branch, Islamic Azad University, Shoushtar, Iran \\ Rahmatabady@gmail.com \\ Kourosh Pashaei \\ Department of architecture, College of Engineering, Boroujerd Branch, Islamic Azad University, \\ Boroujerd, Iran \\ Mehdi Rezaei \\ Department of architecture, College of Engineering, Shoushtar Branch, Islamic Azad University, \\ Shoushtar, Iran \\ Tahereh Rahmatabady \\ Department of architecture, College of Engineering, Kangavar Branch, Islamic Azad University, Kangavar, \\ Iran
}

\begin{abstract}
ABSTRATCT
Zagros Mountains located in the west of Iran. In this region, nature, climate and environment is distinguished than other parts of the country. What has caused this difference certainly is Zagros Mountain. Special architecture of the dwellings and formation of many villages of this region have been affected by them. Zagros region tourism potentials and attractions have been considered by internal and external tourists in recent decade. Environmental and natural elements like: river, waterfall, forest, wildlife natural species and ecosystem and man-made elements like stair shaped houses, compatible with climate architecture and harmonization between construction and context have great effects on eco-tourists gathering. Researchers in this article scrutinize ecotourism features in a village (located in the heart of the Hawraman, in the middle Zagros) called Hajiij as a valuable texture village. Then the impacts of tourist on human and environmental components of the village and present threats and challenges have been studied. Beside field researches, questionnaire and interview with residents and officials as two statistical samples are applied in the research. After analyzing gathered data, research findings have been presented quantitatively. Finally strategies to face threats and weaknesses of village ecotourism have been presented. Applying them in a long term will have sustainable effects like reducing poverty, protecting native values and culture, economic development and reducing migration.
\end{abstract}

Keywords: Tourism, Rural texture, Hajiij, Sustainability, Rural texture

\section{INTRODUCTION}

History, culture, lifestyle, and language of every nation are interwoven in a pervasive source so that understanding and knowledge of these elements is just acquired by their direct observation and without knowing these in different societies, social culture won't develop, even it may be destroyed. So tourism in places where cultures destiny is interrelated, is a widespread cultural discourse. Tourists have the message of unity among cultures and it is an instrument for communication between them (Dibaei, 1992, 12). Touring is thought of as an important and new phenomenon in 21th machine-made and its importance is increasing every day in the world; since increasing technology, machine-made life of nations and 
development of new inventions and explorations that makes man depended on cities, causes a lot of problems to be found in cities (Butler, 2002). According to world tourism organization definition of tourism in 1993, "tourism is any kind of trip including at least one night staying and less than one year away from home" (Swarbrook, 1999, 144). At present most countries in the world have a close competition to interest their own countries capabilities in allocating lion's shares of tourism industry income and simply lead to employment (Moulaei Hashtjin \& Khoshnoud, 2007, 1).

Iran having one million and two hundred hills, one hundred and fifty thousand monuments, attractions and different resources is one of the first ten countries having the world tourist attractions, and one of the first five countries in ecotourism attraction and varieties (Saghaei, 1386:455). Climate variety in Iran is such a way that makes travelling for Iranians and foreigner tourists possible in all seasons of the year. But this country despite having different tourism attractions and because of diverse reasons hasn't still been able to apply this benefit.

On the other hand many countries all over the world have been protecting natural environment and humancultural resources for the past 30 years for the compatibility of development and protection. It finally has led to compilation of sustainable development principles and suggesting different new choices for sustainable tourism such as, sustainable ecotourism.

\section{VILLAGE TOURISM AND ECOTOURISM}

Ecotourism hasn't still been defined clearly. The first definition was proposed by "Hetzer" in 1965. According that ecotourism is based on four major components of reducing undesirable environment effects, respecting native culture, increasing benefits from tourism for local people and tourist satisfaction (Hetzet, 1965, 188). "Weaver" and "Lawton" don't consider ecotourism as a scientific and academic field because of its division in to different parts and lack of integration. They say it is still in its teens and ecological, social, cultural and economic effects should be considered systematically and coherently (Weaver \& Lawton, 2007, 1168).

According to "Goodwin" nature based tourism include types of centralized tourism, exciting motivated tourism and tourism with mild consequences in which major motivation is to benefit wild and genuine nature with species and animal habitats, natural scenes and attractive rivers (Goodwin, 1995, 130).

World Trade Organization (1996) considers two major functions for village ecotourism to be achieved: 1) promoting economical capacity of rural societies for creativity and developing human resources by investing in these regions and verifying village societies economical functions. 2) Helping economical regions out of economic, social, cultural isolation and connecting rural economy to regional, national and international economy respect to globalization processes (Maghsoudi and Lashgarara, 2004:55). The necessity to develop villages than cities is not because of large population of third world countries live in villages rather the problems of migration, unemployment and population density of cities arises from village environment quality (Teodaro, 1989, 44).

\section{DIMENSIONS OF STABILITY IN ECOTOURISM}

Ecotourism has an international significance, since it can be very useful by using cost and benefit models to achieve sustainable development. "Blangy" and "Mehta" have emphasized the important role of ecological regions revived in the field of ecotourism and they know it to be an important approach tourism planning. They also believe ecological revival has the most significant role in ecotourism that can lead to rapid development of tourism and sustainable development in different dimensions (Blangy \& Mehta, 2006, 233). Sustainable tourism responds present needs of tourists and future generation and equilibrates environmental, economic, social and cultural dimensions. It means sustainable tourism wants to measure ecological tolerance capacity, economical measurement possibility and sociocultural acceptance (Elsasser et al, 1995, 17). Sustainable development consist three dimensions of economic, social and ecological. They have a specific structure and a hierarchical system (the following diagram). These dimensions each have a special role in sustainable development. Identifying these roles depends on the subject of the study (Birkmann, 2000, 168). In addition to preserving quality, variety of cultures and different environments, 
sustainable tourism seeks to increase income and promote village life level and make a balance in three dimensions of tourism, local residents and the place of tourism (Akbari \& Bemanian, 2008, 134).

The major motivation in constant ecotourism is, travelling to nature and visiting a region's natural attractions including form features and its native culture. Ecotourism requires human resources more than welfare and staying installations, so ecotourism doesn't have huge investment attraction but it provides many job opportunities that its advantages directly go to natives. It should be noted that interference in nature and natural landscapes results in their context destroying and unidentity (Akbari \& Bemanian, 2008, 134).

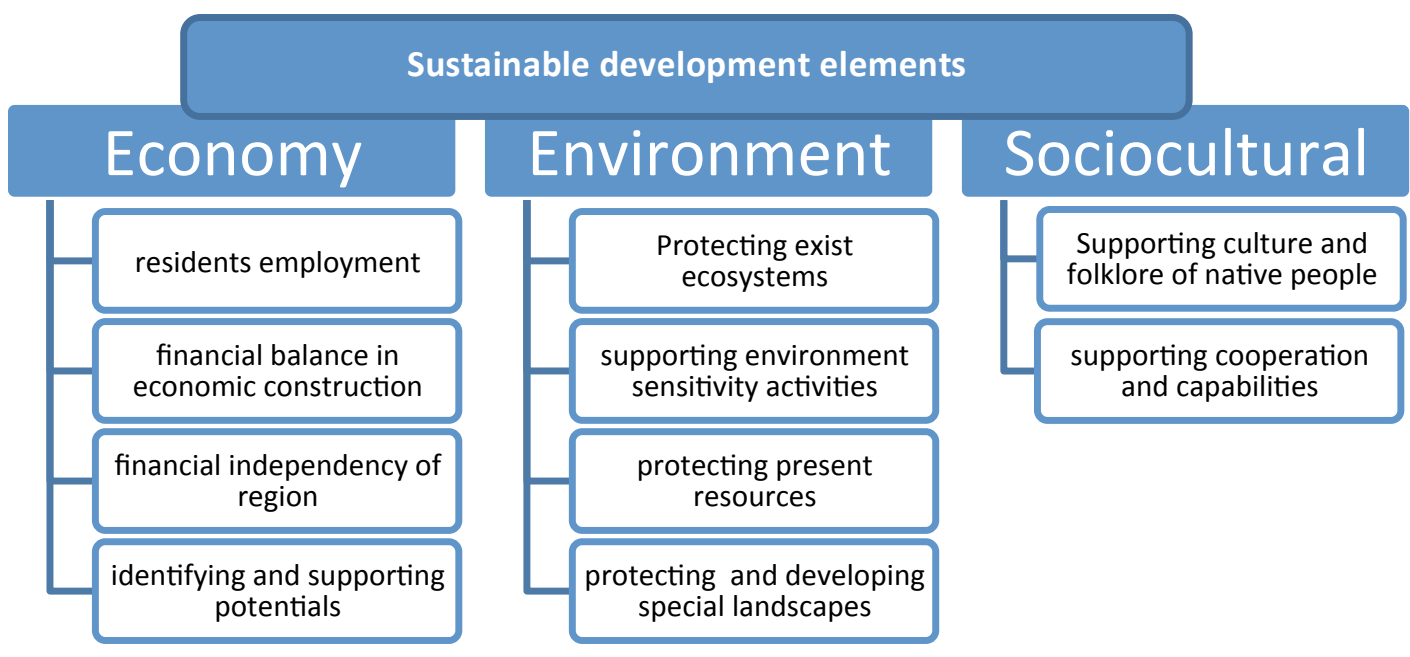

Tourism Sustainable development

Diagram 1: Dimensions of Tourism Sustainable development (University of Dortmund 2000:14)

\section{NATURAL ENVIRONMENT OF HAJIIJ VILLAGE}

Hajiij is a suburban village of Pawa, Hawraman region and Kermanshah province. It is located at 34 and $123 \mathrm{kms}$ away from Pawa and Kermanshah respectively. It has a mild and mountainous climate. In summer and spring it has a pleasant climate and in autumn and winter is cold. Sirwan river- the largest river in the province passes near the village. Although there are no valid proofs about its history, the presence of "Abidolla" shrine known as "Kowseh Hajiij" shows the village's ancient history. The people speak Kurdish language and Hawrami dialect. This dialect is just spoken in Hawraman region and UN has registered it as an extincting dialect (Wurm, 2001, 90).

Table 1: Climate and geographical features of the Hajiij Village (source: Kermanshah province aerology site)

\begin{tabular}{|l|l}
\hline Annual normal temperature & $15.1 \mathrm{C}$ \\
\hline Absolute minimum temperature & -13 \\
\hline Absolute maximum temperature & 41.1 \\
\hline Wind direction & North western \\
\hline Normal wind speed & $4 \mathrm{~km} / \mathrm{h}$ \\
\hline Height from sea level & $850 \mathrm{~m}$ \\
\hline Latitude & $35 / 95$ \\
\hline Longitude & $46 / 20$ \\
\hline Rain fall average & $1050 \mathrm{~mm}$ \\
\hline Annual sun dial & $2750 \mathrm{~h}$ \\
\hline Climates & Mild and humid \\
\hline Plants & pasture covered by \\
\hline
\end{tabular}




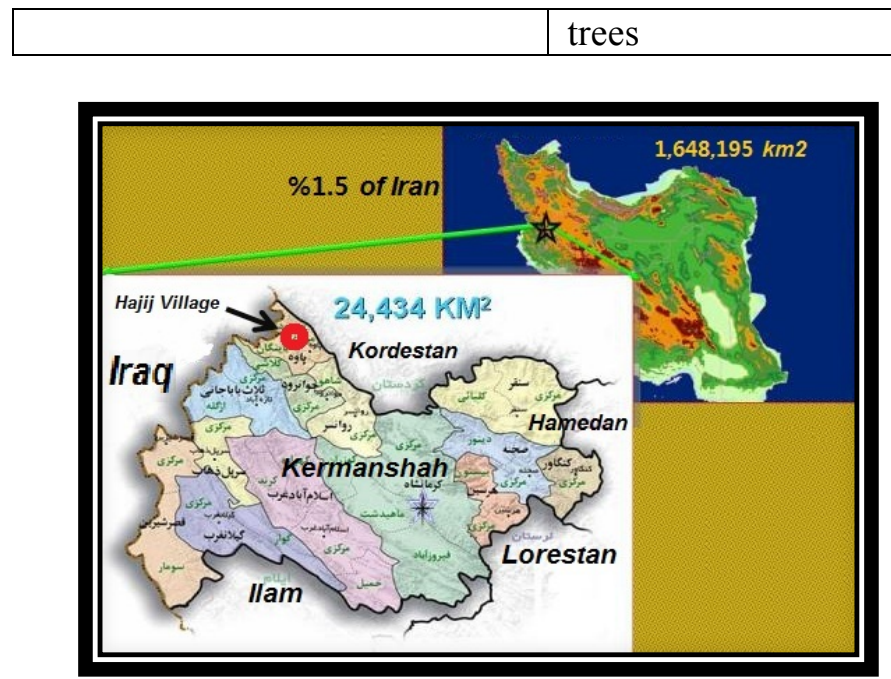

Picture 1: Situation of Hajiij village in the province and Iran

Based on 2011 census, the village has 1036 people. People income is often from gardening and animal husbandry. Being mountainous, in this region farming is not possible, instead gardening is flourishing. Fruits like, nut, Pomegranate and grapes are its most important products. Dried whey, milk, animal oil and butter are the main milk products. Keeping and nurturing different birds is common. Some people are selfemployed and work in handicrafts. The village context is compressed and centralized in a valley on the northern mountain foot. General slope of the village is more than 40 percent. The building main orientation is toward the south, south eastern and south western, to get the greatest rate of heat and sunshine special in winter. The village context has followed the mountainous geography. In addition to houses orientation, gardens formation is based on climate and topographical factors. General context of the village is in the middle of hillside to keep them safe from flood in the bottom and cold winds on top of mountains and have access to water. On the other hand there is no house on the southern mountain foot that is not faced to the sun; instead gardens and farm lands observable to residents are located there. So the best alternative for houses is the one in the picture. The real connection between human and nature can be seen here. The rigid and strong body of the mountain is carved. Flat and high walls are made by the same stones and in that restricted place a house is formed with same color (of the mountain) but the form has changed. The windows color is due to their beliefs blue (Rahmatabady \& Amjadian, 2012, 93). Stone walls which are usually about 3 to 7 meters high, often built without mortar. Just timbers are inserted between courses of stones to increase residence against vertical and horizontal earthquake forces. The wall thickness along with clay and straw layer and plaster layer in the inner wall, causes more resistance and decreases heat fluctuations. The houses flat ceiling, are covered by wooden bars and filled with clay and straw. The common used materials include, stone, wood and clay mortar. Metal or brick are never used.
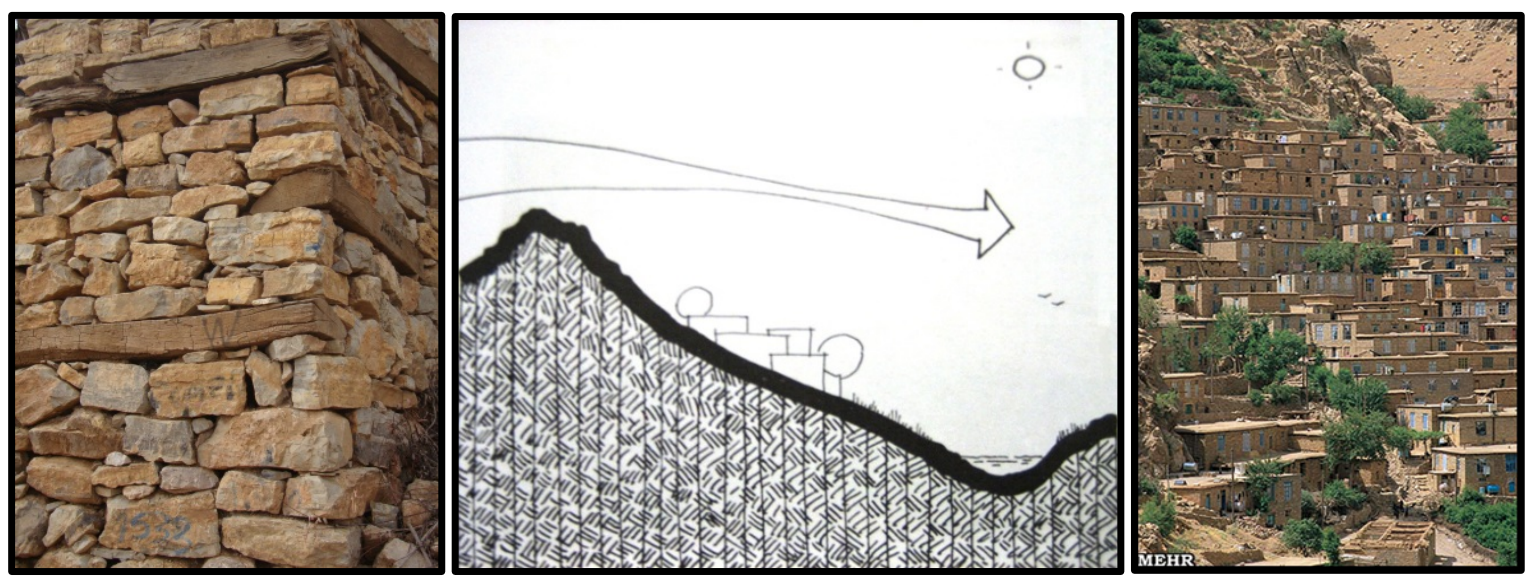

Picture 2 (left): Materials used in the wall. Pictures 3 and 4: Position and orientation of Hajiij (source: authors) 


\section{POTENTIALS AND TOURISM ATTRACTIONS OF HAJIIJ GEOGRAPHICAL ATTRACTIONS}

Sirwan River: It originates form Kurdistan province and it is the largest river in Kermanshah and Kurdistan province. After traveling $215 \mathrm{kms}$ meanderings and near many cities and villages goes out from Kermanshah and enters into Iraq. The ministry of energy is building a dam on it with huge equipment to use the water in western cities lands and preventing its exit from Iran. The dam is 250 meters high and is being built 4100 meters away from the village. The river has made many plant and animal species and organisms live there; it has also caused climate adjustments.

Kani Bel spring: Sirwan brings many waterfalls and springs along such as Kani Bel spring which has $5 \mathrm{~m}^{3} / \mathrm{s}$ flow with healing property. The dam project will destroy this spring and many other living species and ecosystems. The disaster is that about 70 houses of Hajiij will be drowned in water because they are lower than the dam height. The officials have proposed that the residents build their houses in higher places by buying their houses.

Intact and safe nature: Since the region is mountainous and difficult to pass, has less been influenced by destructive impacts of technology and machine and less constructions has been made in it. It also includes intact ecosystems and nature and wildlife species. Nature without audio-visual and environmental contaminations is the interest of tourists. In this way their desire to see the nature and its worth seeing mountains increases.
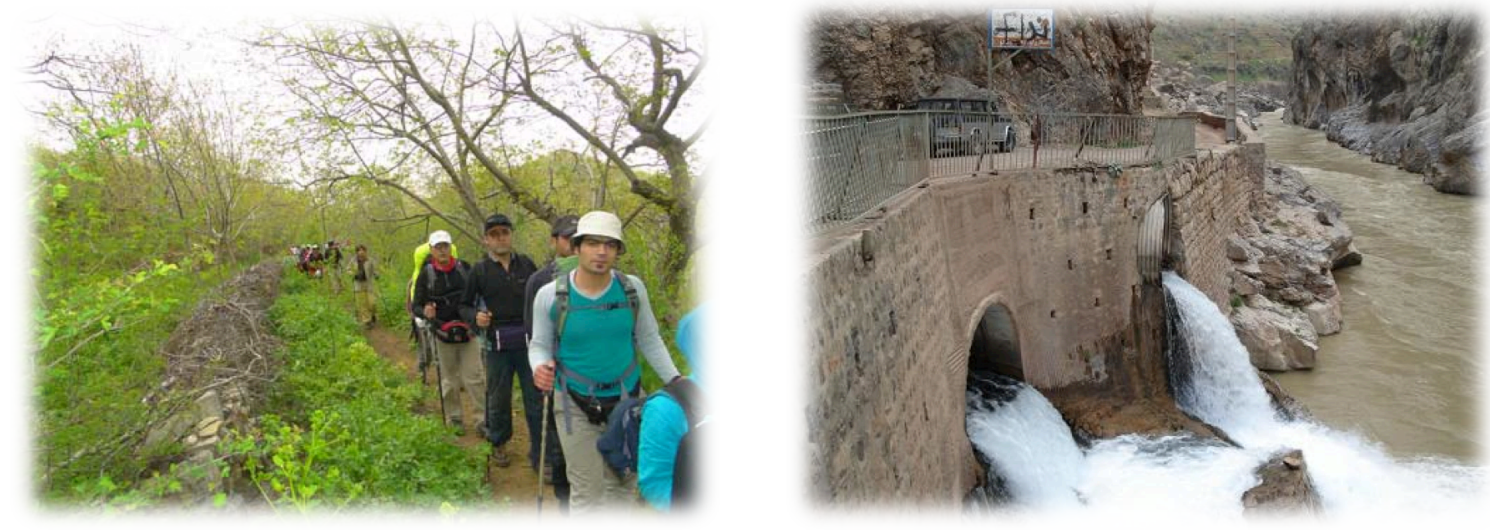

Picture 5: Bel spring eruption into Sirwan. Due to dam operations, the river has been muddy

Picture 6: mountain Climbing as a part of tourist's activities in the region (source: www.davasaz.blogfa.com).

\section{ARCHITECTURAL ATTRACTIONS AND MANKIND-BUILT ENVIRONMENT}

Abidollah shrine: At the beginning and lower part of the village there is a shrine is called "Kowseh Kajij". Its construction is four brick arched. According to local people Abidollah is one of Imam Mousa Kazem's descendents. Other valuable monuments are "Khanghah" and "Cheleh khane". One of the most important ceremonies held is recite and song of dervishes. They hold in special days and by gnostic songs and dances.

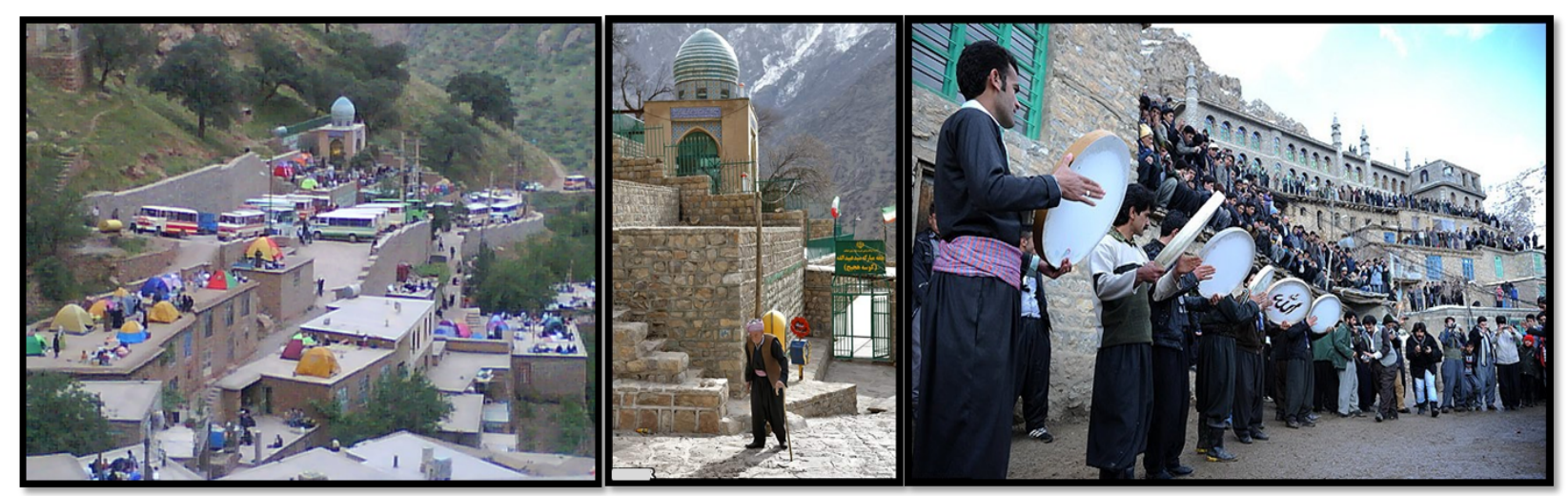


Pictures 7, 8 and 9: Imam Abidollah shrine will residents religious ceremonies. (Source: authors)

Village texture and constructions body: Constructions that have developed according to their bed, their form are stair shape on each other. This has caused shared semi public and private spaces that strengthen social relationships and interactions. Passes have combined with yards, porticos and roofs of the houses and highlights people's presence in these spaces. They are narrow with many steps that sometimes are roofed. No sign or noise of automobile or motorcycle is heard by residents and tourists.
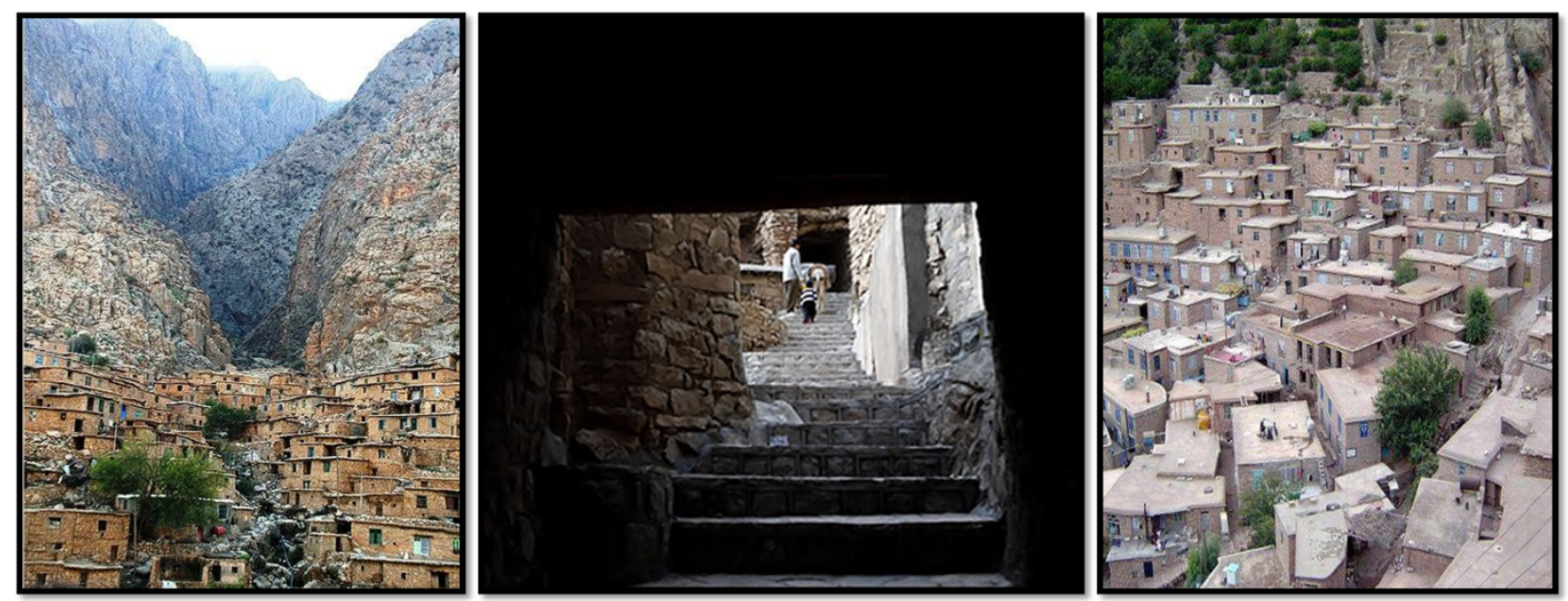

Pictures 10, 11 and 12: Notice to passes and compatibility of houses with bed (source: www.davasaz.blogfa.com)

\section{LOCAL AND CULTURAL ATTRACTIONS}

clothing: The village clothing is native, like other Kurdish residents of Kurdistan. Threats compatible with cultural values and affected by mountains context of the region, since activities are done more freely.

Handicrafts and industries: different kind of handicrafts such as: short-napped coarse carpet (Gelim), JaJim (thin carpet), Giveh (woven shoes), hand kerchief, basket, native clothes are produced specially by women. Majority of people are working but about one tenth make a living of them.
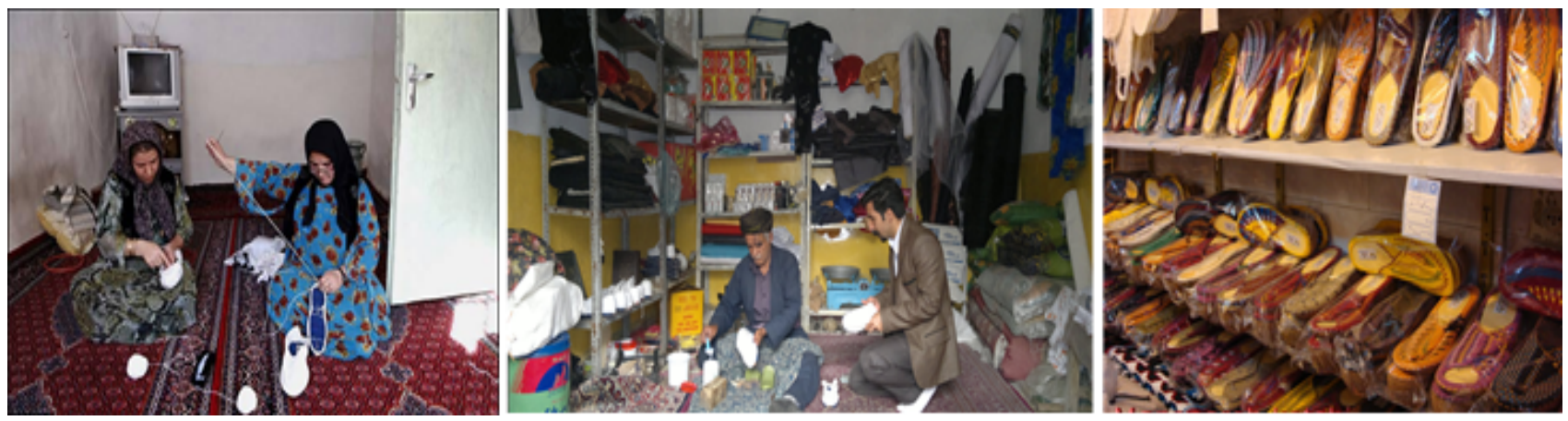

Picture 13, 14 and 15: Some dwellers make money with producing handicrafts (source: authors).

Products: Fish farming because of the existence of the river, different kinds of milk products and animal oil are presented to visitors. The desired amount of rainfall has produced different green gardens and fruits like pomegranate, nut and grape are the main products of the village. To access valid attainment about the positive and negative effects of tourism, the author has repeatedly presented in the village and applied field researches, in addition used questionnaire and interview with residents. The priorities in gathering data were experienced and informed native people. To increase credibility of research, organization research, questionnaire, interview with cultural inheritance officials, villagers home institution, village governor and 
council were emphasized. The research was based on varied questions in order to study ecotourism challenges and threats in the village to achieve contrast ways and promote strength and opportunities.

\section{THE TESTING AND DATA GATHERING}

43 people from the residents were participated in the test. Thirty people continued the test (No.1 statistical population). 22 officials of which twelve people continued the test (No.2 population). To increase research validity, after statistical analysis results have been shown quantitatively by the help of statistical experts. Five options: (1) never, (2) somewhat, (3) average, (4) high and (5) very high have been considered for answering the questions. The range of each is, 0 to 20,20 to 40,40 to 60,60 to 80 and 80 to 100 respectively. And (i.e. 10, 30, 50, 70, and 90 is the average of each class. For example in a question like to what extent tourists visiting disturb the resident privacy and peace? 12 responses of dwellers were "never", 13 responses were a little and in this way. By applying $\sum_{i=1}^{n}(f i * k i) / \mathrm{n}$ in which $\mathrm{f}_{\mathrm{i}}, \mathrm{k}_{\mathrm{i}}$ and $\mathrm{n}$ indicates the frequency, average of each class and the number of statistical samples respectively. Found numbers that are from 10 to 90 indicates quantitative value of every class. Research finding have been shown in Histogram in which blue and red statistical bars show residents (population 1) and officials (population 2) respectively.

Table 2: The quantitative result of the question: what extent tourists visiting disturb the resident privacy and peace?

\begin{tabular}{|l|l|l|l|l|l|l}
\hline $\begin{array}{l}\text { Number of } \\
\text { each class }\end{array}$ & $\begin{array}{l}\text { Value of each } \\
\text { class }\end{array}$ & $\begin{array}{l}\text { Range of } \\
\text { each class }\end{array}$ & $\boldsymbol{k i}$ & $\boldsymbol{f i}$ & $\boldsymbol{f i} * \boldsymbol{k i}$ & $(\boldsymbol{f i} * \boldsymbol{k i}) / \mathbf{n}$ \\
\hline 1 & never & $0-20$ & 10 & 12 & 120 & 4 \\
\hline 2 & little & $20-40$ & 30 & 13 & 390 & 13 \\
\hline 3 & average & $40-60$ & 50 & 3 & 150 & 5 \\
\hline 4 & high & $60-80$ & 70 & 2 & 140 & 4.6 \\
\hline 5 & Very high & $80-100$ & 90 & 0 & 0 & 0 \\
\hline & Sum & & & 30 & 1440 & $\mathbf{2 6 . 6}$ \\
\hline
\end{tabular}

\section{DATA ANALYSIS AND STATISTICAL APPROACH}

Questions were designed to reflect strengths, weaknesses, opportunities and threats of ecotourism in the village by the four following approaches with the minimum errors.

Sociocultural approach: In this approach the rate of tourists effects on village culture and vice versa has been studied; the impact of tourists on traditional attractions, native culture (clothing, dialect and interactions) and tourists being effected by native culture.

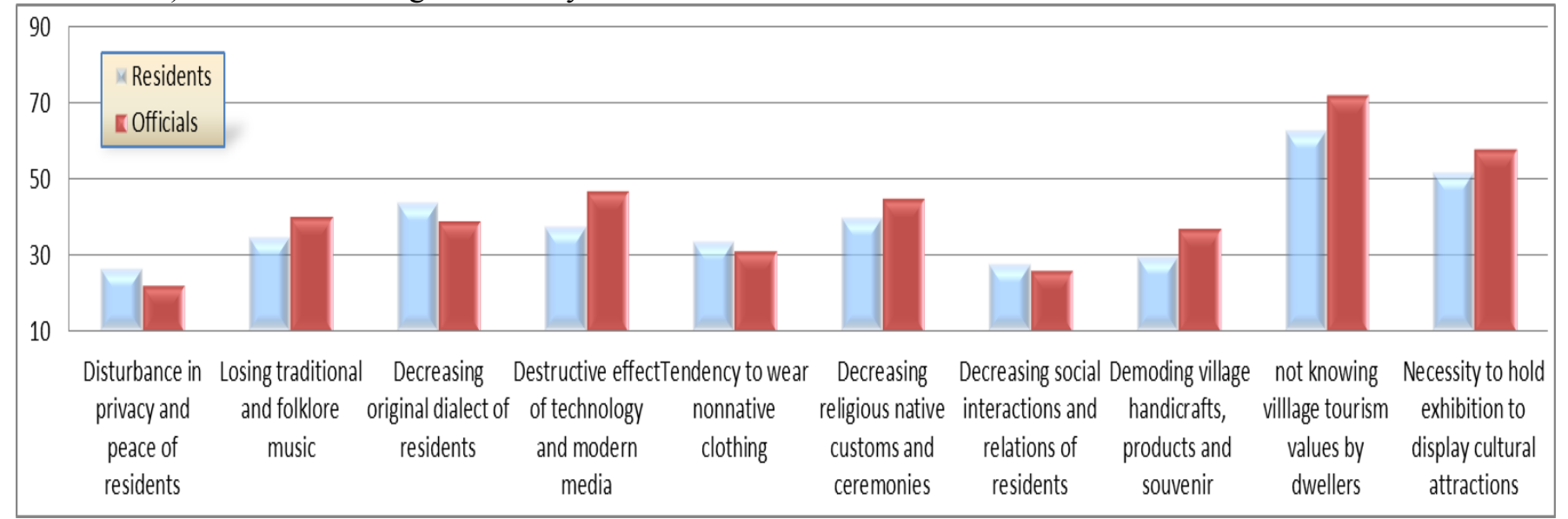

Diagram 2: analyzed data in Sociocultural approach for two statistical population villagers (blue bars) and officials (red bars) 
Economical approach: another approach which residents and officials believe has an important role is economic aspects of tourism. By design different questions such as the impact rate of tourists on village economy, residents migrations and maintaining village potentials on tourists attractions, the results were as follow:

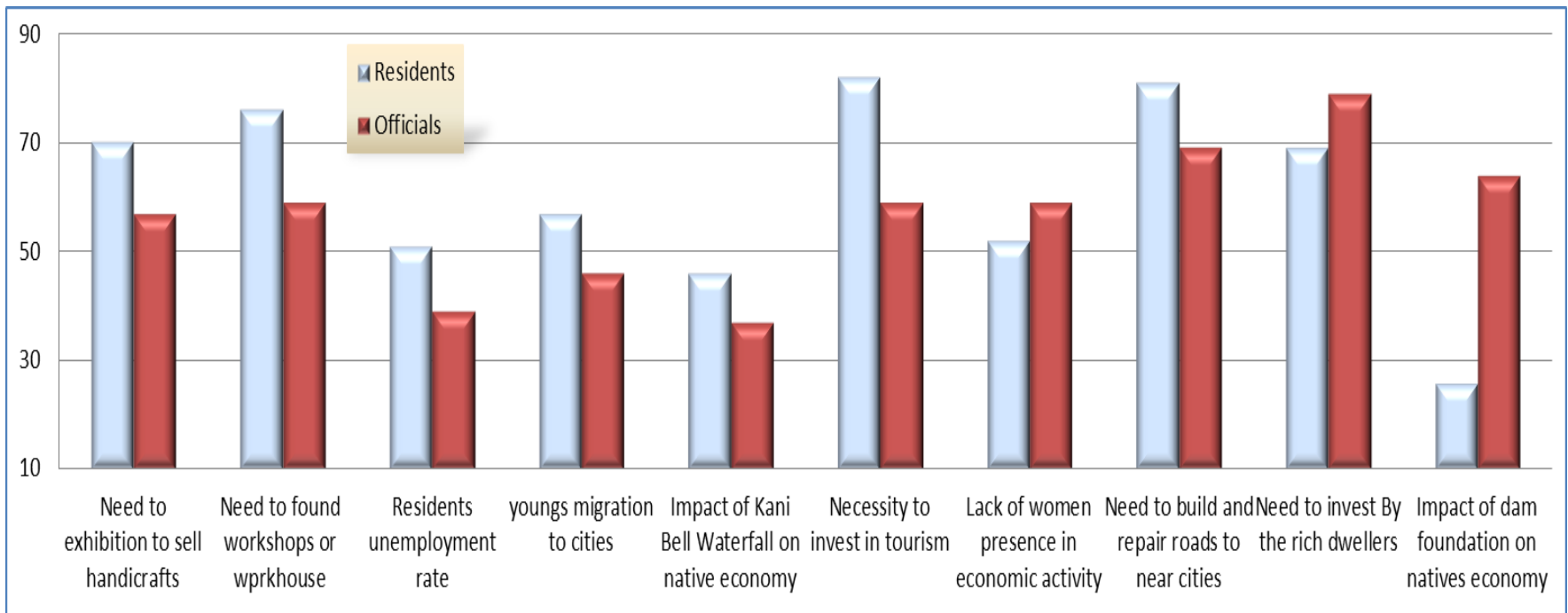

Diagram 3: analyzed data in the economical approach for two statistical population villagers

Environmental- physical approach: questions designed based on environmental- physical approach have dealt with the role of environmental resources in attracting and directing tourists: road quality, constructions architecture and form, pavement of pathways and alleys. Tourists guide signs, parking, passengers resting and staying places. The following results have been achieved:

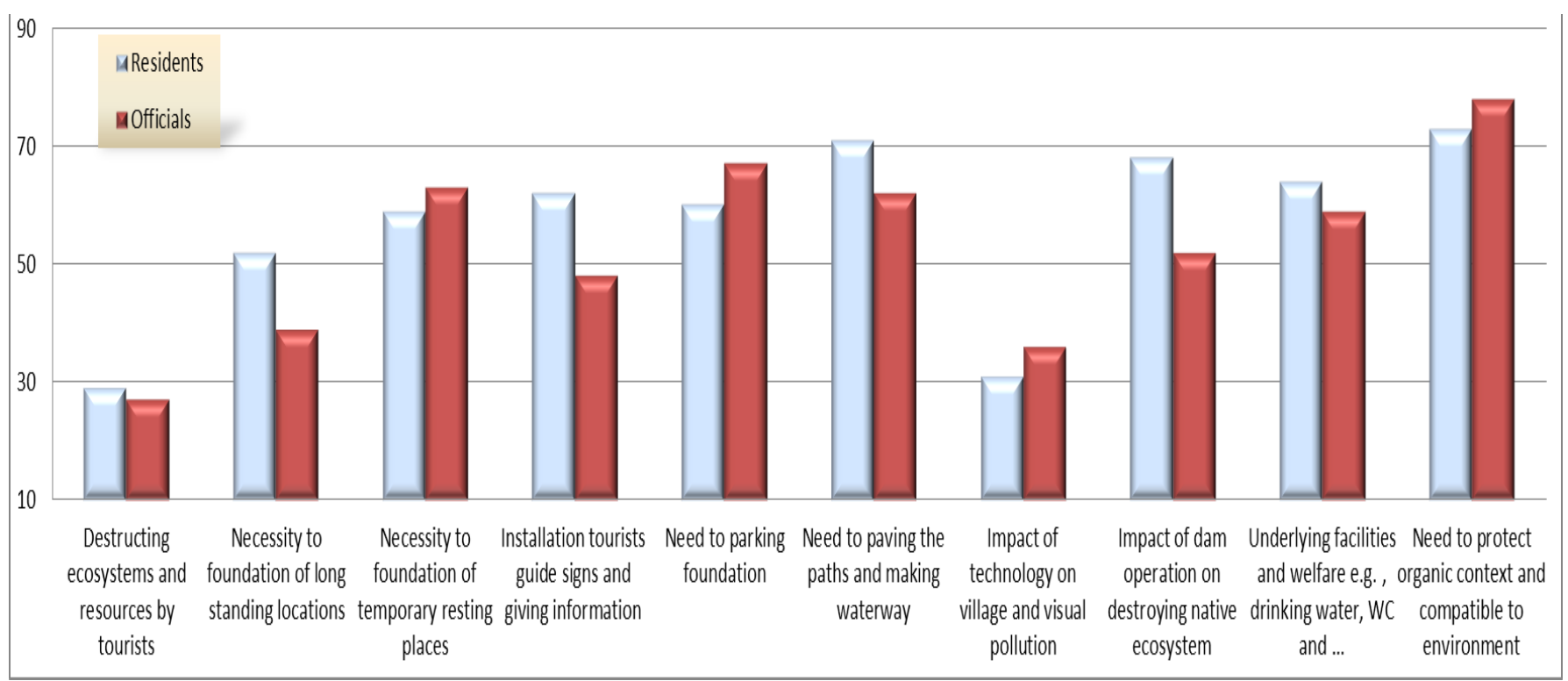

Diagram 4: analyzed data in the environmental-physical approach for two statistical population villagers 


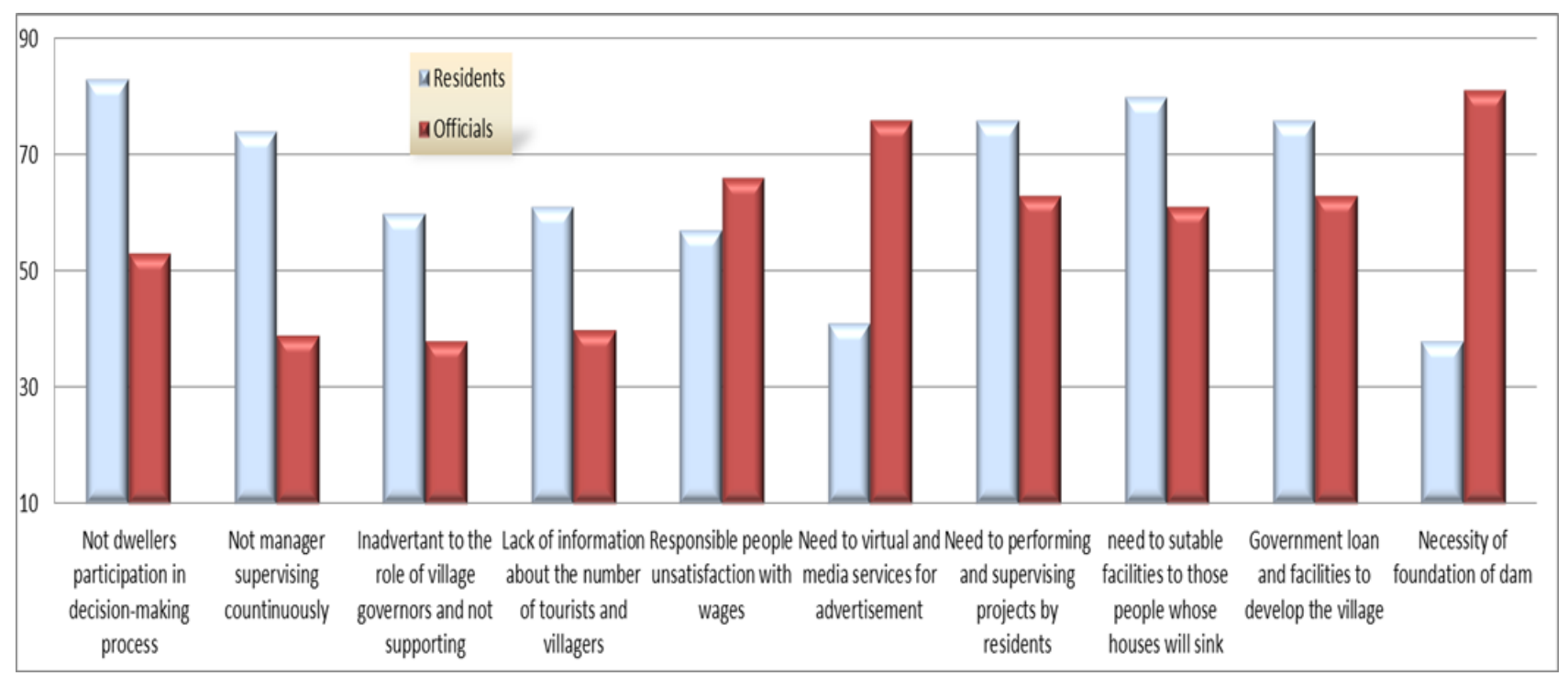

Diagram 5: analyzed data in the management approach for two statistical population villagers

Management approach: This approach emphasizes the role of managers and organizations in the attracting and keeping tourists. The people participation in decision-makings, government facilities, underlying utilities and welfare, tourists statistics, village official wages, government advertising and projects supervision are studied.

\section{RESEARCH STATISTICAL FINDINGS}

The important research findings in the four mentioned fields and based on analyzed statistics as the following table show that:

Table 3: result of the research in the analyzed approach

\begin{tabular}{|l|l|l|l|l}
\hline \multirow{2}{*}{ Approach } & \multicolumn{2}{l}{ Statistical sample } & Percent of every approach & Number of every class \\
\hline \multirow{2}{*}{ Ecio-cultural approach } & Residents & $\mathbf{1 / 3 9 \%}$ & $\mathbf{2}$ \\
\cline { 2 - 4 } & officials & $\mathbf{7 / 4 1 \%}$ & $\mathbf{3}$ \\
\hline \multirow{2}{*}{$\begin{array}{l}\text { Physical-environmental } \\
\text { approach }\end{array}$} & Residents & $\mathbf{6 1 \%}$ & $\mathbf{4}$ \\
\cline { 2 - 4 } & officials & $\mathbf{8 / 5 6 \%}$ & $\mathbf{3}$ \\
\hline \multirow{2}{*}{ Management approach } & Residents & $\mathbf{9 / 5 6 \%}$ & $\mathbf{3}$ \\
\cline { 2 - 4 } & officials & $\mathbf{1 / 5 3 \%}$ & $\mathbf{3}$ \\
\cline { 2 - 4 } & Residents & $\mathbf{6 / 6 4 \%}$ & $\mathbf{4}$ \\
\cline { 2 - 4 } & officials & $\mathbf{5 8 \%}$ & $\mathbf{3}$ \\
\hline
\end{tabular}

Management and economical approach which have achieved the highest scores respectively include more weaknesses and are subject to more serious threats. These challenges must be change to opportunities or strengths by adopting economical and management strategies. Although villagers believe that dam building is a national project, since it destroys one third of houses and a part of gardens they are not willing it to be finished. They also believe by expending expenses, great deal of time and destroying ecosystems, there is no guaranty to attract tourists. Receiving indemnity is the most significant anxiety of those whose house is sunk. They state that by this little amount of money they can rent a house in city although they have no tendency to migrate. The government is considered upper grounds of village for building new houses by giving facilities and transportation of building materials (following picture). The residents complain, is that related organizations don't participate them in village affair, although the organizations don't supervise village projects continuously too. Village governors and councils aren't motivated to take actions since they are not paid properly. 


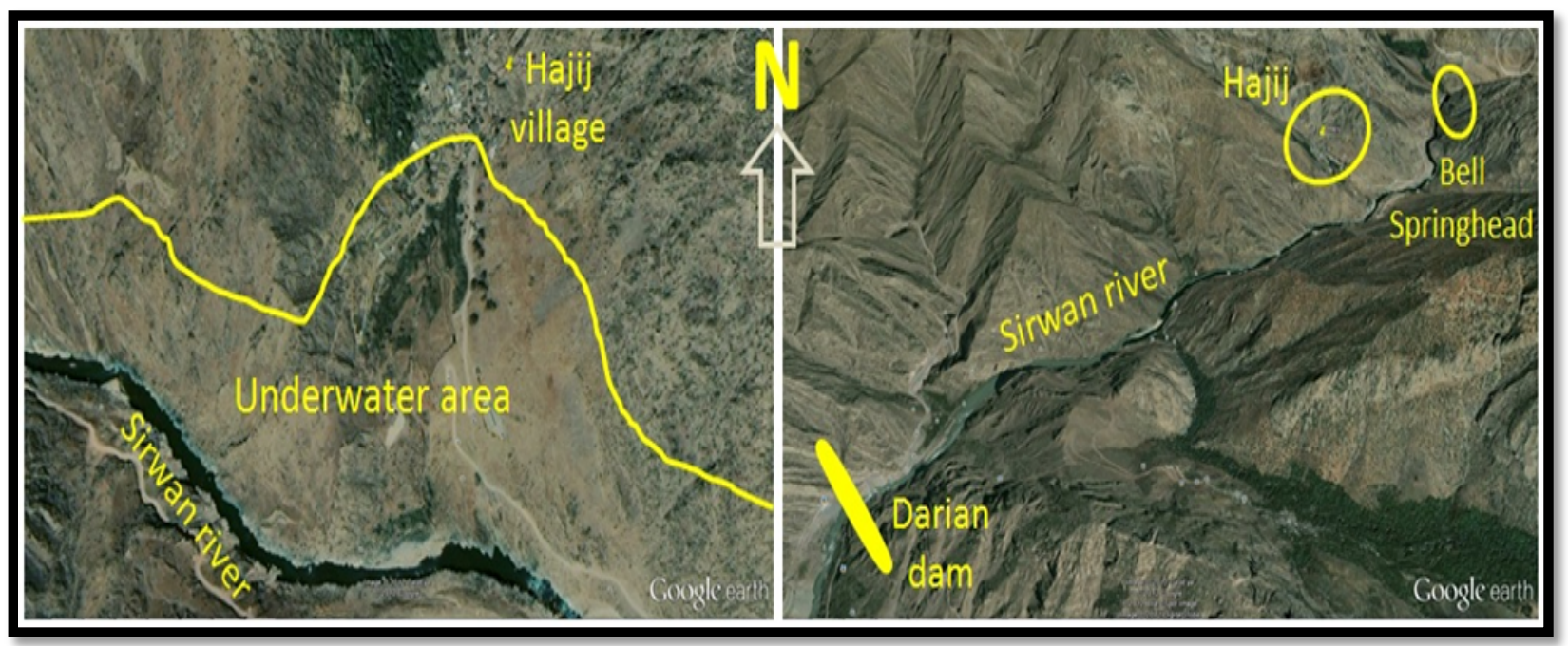

Picture 16 (left): underwater area of the region. Picture 17 (right): position of Hajiij among Darian Dam, Bell spring (source: Google earth website).

Since the link road of village to cities is difficult to pass and has a low quality and safety, it's a big obstacle for tourists entrance. Village reconstruction, paving pathways and directing surface water are cases that increase tendency of tourists to walk at village. Luckily with help of village house institution, valuable context reviving operations such as: pavement of pathways and making waterways have started in 2012 (The plan constructors are author's students).

The villagers are often producing handicrafts inside or semipublic spaces of the houses and they don't have any special place to exhibit and sell them. If a part of the village is devoted to workshop and exhibition to produce and present handicrafts and souvenir, it will cause coherency in their activities and centralizes tourists.

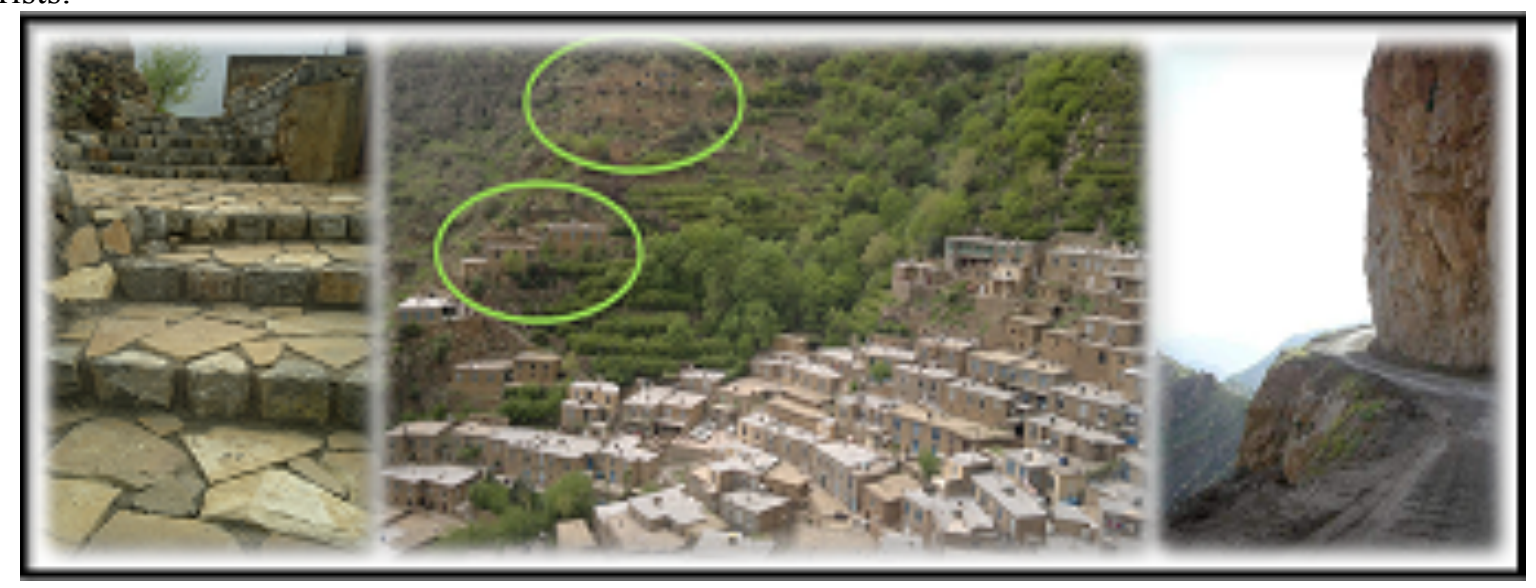

Picture 18 (left): beginning the pavement of pathways, picture 19 (middle): constructing new houses at the top of the village. Picture 19 (right): improper link road of the village to the cities (Source: authors).

One of the strategic management methods that are capable to interfere with crisis facing systems is classifying information in a table based on tour factors: strength, weakness, opportunity and threat. This method which is highly use in fields by researchers like ecotourism, identifies the system tasks which has to be faced and indicates where remedies should be made and where preventions should be sought. 
Table 4: presentation internal analysis (i.e. weakness and strength) and external analysis (i.e. threats and opportunities) of ecotourism in the village based on SWOT table.

\begin{tabular}{|c|c|c|c|c|}
\hline & Threat & Opportunity & Weakness & Strength \\
\hline \multirow{4}{*}{ 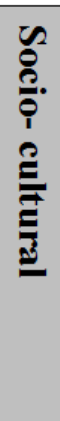 } & Weakening native culture by tourists & $\begin{array}{l}\text { Propagating and } \\
\text { presentation of } \\
\text { residence clothing in } \\
\text { tourists interactions }\end{array}$ & $\begin{array}{l}\text { Residents privacy and peace } \\
\text { disorder }\end{array}$ & $\begin{array}{l}\text { Native culture values } \\
\text { propagation }\end{array}$ \\
\hline & $\begin{array}{l}\text { Change in people and the young } \\
\text { clothing }\end{array}$ & $\begin{array}{l}\text { Preserving and } \\
\text { broadcasting folklore } \\
\text { music }\end{array}$ & $\begin{array}{l}\text { Resistants' Inability to guide } \\
\text { and help tourists }\end{array}$ & $\begin{array}{l}\text { Reviving native } \\
\text { values from residents } \\
\text { viewpoints }\end{array}$ \\
\hline & $\begin{array}{l}\text { Weakening traditional and ancient } \\
\text { attraction }\end{array}$ & $\begin{array}{l}\text { Emphasize on native } \\
\text { dialect }\end{array}$ & & \\
\hline & $\begin{array}{l}\text { Modern media(satellite \& internet) } \\
\text { prevents the young and natives from } \\
\text { their genuine culture }\end{array}$ & $\begin{array}{lr}\begin{array}{l}\text { Displaying } \\
\text { ceremonies }\end{array} & \text { native } \\
\text { customs } & \text { and } \\
\end{array}$ & & \\
\hline \multirow{8}{*}{ 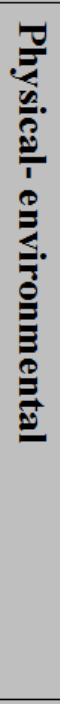 } & $\begin{array}{l}\text { Shakes from mountain destroying and } \\
\text { its destructive effect on neighboring }\end{array}$ & $\begin{array}{l}\text { Preserving of } \\
\text { organic landscape }\end{array}$ & $\begin{array}{l}\text { Lack of possibility for long- } \\
\text { time tourists }\end{array}$ & $\begin{array}{l}\text { Fresh an unpolluted } \\
\text { air }\end{array}$ \\
\hline & Sinking a part of village in dam water & $\begin{array}{l}\text { Constructing } \begin{array}{r}\text { of } \\
\text { organic } \\
\text { buildings }\end{array} \text { tourism } \\
\end{array}$ & $\begin{array}{l}\text { Lack of temporary resting } \\
\text { places for tourists }\end{array}$ & $\begin{array}{l}\text { Green nature and } \\
\text { jungles }\end{array}$ \\
\hline & $\begin{array}{l}\text { The region ecosystem weakening by } \\
\text { founding warehouses, worker's houses }\end{array}$ & $\begin{array}{l}\text { Respect to the } \\
\text { natural environment } \\
\text { and maintaining its } \\
\text { healthy }\end{array}$ & $\begin{array}{l}\text { The lack of tourists guiding } \\
\text { signs and proper information }\end{array}$ & $\begin{array}{l}\text { Peace and quiet in } \\
\text { locals due to lack of } \\
\text { automobile }\end{array}$ \\
\hline & $\begin{array}{l}\text { Development of village by non- } \\
\text { compatible constructions with context } \\
\text { and climate }\end{array}$ & & $\begin{array}{l}\text { Lack of stone pavements of } \\
\text { paths }\end{array}$ & $\begin{array}{l}\text { Organic and } \\
\text { traditional architecture } \\
\text { of village }\end{array}$ \\
\hline & $\begin{array}{l}\text { Living species and organisms destroying } \\
\text { and sinking by dam water rise }\end{array}$ & & Lack of parking and rest rooms & $\begin{array}{l}\text { Unique and stair shaped } \\
\text { context of village }\end{array}$ \\
\hline & Improper linking road & & $\begin{array}{l}\text { Climate changes during } \\
\text { seasons }\end{array}$ & \\
\hline & & & $\begin{array}{l}\text { Not coverage well mobile } \\
\text { phone }\end{array}$ & \\
\hline & & & $\begin{array}{l}\text { Not directing surface waters } \\
\text { and the lack of waterway }\end{array}$ & \\
\hline \multirow{3}{*}{ 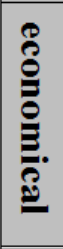 } & & $\begin{array}{l}\text { Promoting } \\
\text { economical } \\
\text { developing projects }\end{array}$ & $\begin{array}{l}\text { Not exhibitions to display } \\
\text { native products and } \\
\text { handicrafts }\end{array}$ & $\begin{array}{l}\text { Resident investment } \\
\text { in promoting services } \\
\text { and tourists attractions }\end{array}$ \\
\hline & & $\begin{array}{l}\text { Decreasing } \\
\text { unemployment }\end{array}$ & $\begin{array}{l}\text { Lack of fairs to produce } \\
\text { handicrafts }\end{array}$ & $\begin{array}{l}\text { Multi dimension } \\
\text { village economy }\end{array}$ \\
\hline & & $\begin{array}{l}\text { Reducing migration } \\
\text { to cities }\end{array}$ & & $\begin{array}{l}\text { Increasing village } \\
\text { economical potentials }\end{array}$ \\
\hline \multirow{5}{*}{ 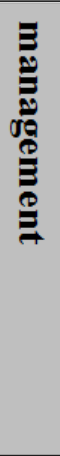 } & $\begin{array}{l}\text { Not participating dwellers in decision } \\
\text { making }\end{array}$ & $\begin{array}{lr}\text { Encouraging } & \text { and } \\
\text { supporting } & \text { rich } \\
\text { dwellers } & \\
\end{array}$ & $\begin{array}{l}\text { Not continual supervision by } \\
\text { the officials }\end{array}$ & $\begin{array}{l}\text { Accelerating facilities } \\
\text { to those whose house } \\
\text { has been destroyed }\end{array}$ \\
\hline & $\begin{array}{l}\text { Inadvertent in maintaining tourists } \\
\text { attractions by the officials }\end{array}$ & & $\begin{array}{l}\text { Ignoring village governors } \\
\text { role and not supporting them } \\
\text { by governor }\end{array}$ & $\begin{array}{lr}\text { Future } & \text { projects } \\
\text { performing } & \text { and } \\
\text { supervising by villagers }\end{array}$ \\
\hline & $\begin{array}{l}\text { Not providing those house have sunk in } \\
\text { water with facilities }\end{array}$ & & $\begin{array}{l}\text { Not perceive information } \\
\text { about the village and } \\
\text { dwellers }\end{array}$ & \\
\hline & $\begin{array}{l}\text { The lack of underlying facilities and } \\
\text { welfare }\end{array}$ & & $\begin{array}{l}\text { Not estimating the number } \\
\text { of tourists and passengers }\end{array}$ & \\
\hline & $\begin{array}{l}\text { Dwellers unawareness about tourism } \\
\text { values of their village }\end{array}$ & & $\begin{array}{l}\text { Insufficient income of } \\
\text { responsible people }\end{array}$ & \\
\hline
\end{tabular}

\section{CONCLUSION AND SUGGESTION}

Government managers should revise their management approaches. They should elicit the precise statistical information of village and tourists to identify village tourism capacities clearly. In sustainable ecotourism cycle, host people are one of the significant components. Ignoring them causes losing tourism opportunities. Since ecotourism doesn't require great budgets, managers forget its importance. Whereas with this little budget, more economical flourishing is built both for people and government. Providing and developing underlying facilities, considering functional and aesthetic concepts and principles, to achieve visual unity and quality satisfies tourists. Such village's development should be performed in such a way that their formation and constructional change meet in a long continuous development process. Gradual- 
historical development is a firm development based on accepted paradigms and concepts that leads to totally organized and sustainable village environment. Continuous, establishment of people in villages reflects maintaining economy culture and civilization resources of a society. By protecting village ecology and its genius aesthetics qualities, we can propagate its rapid technological conforming and its industrial new economic systems as well. In this way besides propagating the reach culture, we can strong then culture and civilization bases in villages.

To sum up the following principles in village ecotourism development lead to preserving natural resources and human capitals, economic Self-sufficiency and preventing culture annihilation and finally results in sustainability.

1- Allocating purposeful budgets and government facilities to tourism potential villages

2- Government supervising of village development and preventing tactless constructions which destroys visual qualities of buildings and their views.

3- Maintaining organic context, physical stability and compatibility with its developing bed.

4- Government cooperation in developing village with dwellers in all steps such as: decision-making process supervision and performance, to increases people sensitivity to their living environment quality.

5- Promoting underlying utilities and welfare like roads qualities, developing link roads, drinking water, parking, rest room.

6- Temporary and long-time staying places for ecotourists according to their needs.

7- Workshops or productions foundations to employ the residents and women high presence and wide range participations of natives.

8- Fair foundations including cultural (to display native attractions), handicrafts, productions and village souvenir.

9- Using media and virtual spaces: internet websites, weblogs, media and news agencies in villages and propagating tourist's attractions.

10- Not using or emphasizing technology in great details, imagining its comfortableness and welfare utilities, due to visual pollution. Because ecotourists prefer observe genuine nature and wild life species (animal and plants) to welfare and resting.

11- Holding conferences and meetings to emphasis ecotourism in academic and scientific associations, and benefiting researches, geographical experts ideas, climatic scientists, village planners and natural sciences.

12- Not destroying and pressing nature and preserved regions ecosystems for economic exploitation

13- Investing and cooperation of rich residents and investors.

14- Increasing residents awareness of village valuable context and understanding of ecotourism.

15- Devoting employees work field to valuable context village affairs, in related organizations to elicit exact statistics of village and tourists.

16- Informing and guide sign installation to show barriers and paths and preventing tourists from confusion and losing their time also Installation of brief information signs on ecotourism stations.

17- Information and training host society about sightseer lifestyle and needs, their proper social behavior and interaction with different sightseers.

18- Developing travel agencies offices and centers with government facilities to propagate sightseeing and facilitating ecotourists access to safe and inexpensive transportation systems.

19- Forming ecotourists guides by the cooperation of government organizations to better introduce tourism regions.

\section{REFERENCES}

Akbari, S. and Bemanian, M. (2008). Rural Ecotourism and its role on sustainable architecture: Kandovan village.Village and development journal. Spring 2008 (1): 131-150.

Dibaei, P. (1992). Knowing tourist, Allameh Tabatabaei University. Tehran.

Elsasser, H. Watcher, D. Denzler, S. Frosch, R. Abegg, B. (1995). Nachhaltigkeit im Tourismus, in: Becker, C (pub) Ansatzze fue eine nachhaltige Regionalentwicklang mit.

Goodwin, H. (1995). "Tourism and the environment". Biologist. 42, 3:129-133.

Maghsoudi, T, Lashgarara, F. (2009). Tourism, Development and Village, Jahad mounthly journal, no 264, Tehran. 
Moulaei Hashtjin, N. Khoshnoud, A. (2007). Ecotourism and development with function: Khark and Kharko Islands, Regional conference on geography, tourism and sustainable development, Azad university of Eslamshahr, Eslamshahr.

Paul F.J.Eagles. Stephen F.McCool \& Chirstopher D.Haynes. (2002). Sustainable Tourism in protected areas Guidelines for planning and management.

Rahmatabady. S, Amjadian, K. (2011). The impact of mountains geography of west of Iran on architecture and form of Hawraman dwelling, International Conference on Architecture and Design, "International scientific journal", Geselschaft Adeo, 2012 (1): 91-100

Rakhshani Nasab, H. Zarabi, A. (2009), Challenges and opportunities of ecotourism in Iran, Geographical space journal. 2009(28): 41-54.

Saghaei, M. (2007). Feasibility study of ecotourism at Iran, Regional conference on geography, tourirm and sustainable development, Azad university of Eslamshahr, Eslamshahr.

Swarbrook, J. (1999). Sustainable Tourism Management, Oxford press.

Teodaro, M. (1989). Economic development in the third world countries.Translated by Gholam Ali Farjadi, Program and Budget organization, Tehran.

University of Dortmund (2000), Sustainable regional development for tourism in country Donegal, Republic of Ireland, Faculty Spatial planning.

Weaver, David B. Lawton Laura J. (2007). Twenty years on: The state of contemporary ecotourism research. Journal of Tourism management, 28(2007): 1168-1179.

Wurm. S, A. (2001). Atlas of the world's languages in danger of disappearing new revised edition. UNESCO, Memory of people's series. P. 90

www.Kermanshahmet.ir

www.Googleearth.com

www.ichto.ir

www.Kermanshahmiras.ir

www.davasaz.blogfa.com 